\title{
HOSPICJUM I DOM POMOCY SPOŁECZNEJ ŚW. BRATA ALBERTA W DĄBROWIE TARNOWSKIEJ ${ }^{1}$
}

\section{Historia}

Hospicjum św. Brata Alberta w Dąbrowie Tarnowskiej powstało z inicjatywy ks. prałata Józefa Poremby, proboszcza dąbrowskiej parafii, który był również budowniczym placówki. W roku kanonizacji Brata Alberta Chmielowskiego (1989), ks. Prałat zakłada Stowarzyszenie Pomocy Świętego Brata Alberta (prezesem został wybrany pan Marian Nalepka - nauczyciel liceum ogólnokształcącego), którego zasadniczym celem były starania, aby w parafii został wybudowany dom opieki dla ludzi nieuleczalnie chorych. Propozycja budowy takiego domu spotkała się $\mathrm{z}$ bardzo życzliwym przyjęciem ze strony kurii diecezjalnej. Pozytywna opinia ks. bpa Piotra Bednarczyka, ks. bpa Józefa Gucwy i kanclerza kurii ks. Jana Rzepy zamknęła się w słowach, że w diecezji nie ma takiego domu, a inwestycja ta będzie inwestycją Caritas Diecezji Tarnowskiej.

Po opracowaniu projektu przez inż. Jacka Sumarę i zatwierdzeniu go przez władze administracyjne, rozpoczęto gromadzenie funduszy na budowę obiektu. Stowarzyszenie Pomocy Św. Brata Alberta przygotowało cegiełki, które za pozwoleniem ordynariusza ks. bpa Józefa Życińskiego i życzliwości księży proboszczów, rozprowadzało w parafiach całej diecezji (około 180 parafii przyjęło pozytywnie tę akcję Caritas.) Stowarzyszenie organizowało również w tym celu inne akcje, m.in. festyny charytatywne i bale sylwestrowe. Ks. Prałat zwracał się także z prośbą o pomoc do rodaków mieszkających w Chicago i Nowym Jorku. Jego

\footnotetext{
* MGR URSZUla MRÓZ - dyrektor Hospicjum i Domu Pomocy Społecznej św. Brata Alberta w Dąbrowie Tarnowskiej.

1 Tekst został już opublikowany w: Misericors. 75 lat działalności Caritas Diecezji Tarnowskiej, red. P. Grzanka, Tarnów 2012, wyd. Biblos, s. 393-410.
} 
dwukrotny wyjazd do Stanów Zjednoczonych w roku 1990 i 1997 zaowocował założeniem Stowarzyszenie Pomocy Św. Brata Alberta w Chicago, któremu przewodniczył pan Ryszard Siepiora, ks. Andrzej Jeż, pan Jan Jaworski i pani Krystyna Ryczek. Stowarzyszenie to, wspomagane przez Klub Dąbrowa Tarnowska rozprowadzało cegiełki wśród Polonii zbierając fundusze na budowane dzieło. Również Polonia w Sydney i w innych ośrodkach w Australii wspomogła budowanie Hospicjum przekazując ofiary na ten cel podczas rekolekcji wielkopostnych głoszonych przez ks. prałata J. Porembę. W gronie głównych darczyńców wyróżnili się: ks. prałat Zygmunt Zimowski pochodzący z Kupienina (obecnie przewodniczący Papieskiej Rady ds. Duszpasterstwa Służby Zdrowia w Rzymie) jako fundator windy osobowej, pani Helena Stamarska z USA jako fundatorka hospicyjnej kaplicy, pani Olimpia Włoch z Dąbrowy Tarnowskiej oraz amerykańska i australijska Polonia. Wśród dobroczyńców nie sposób pominąć wolontariuszy z Międzynarodowej Organizacji Charytatywnej IBO, wspierającej budowy charytatywne z siedzibą w Nijmegen w Holandii, którzy przez kilka kolejnych wakacji ofiarnie pracowali przy wykopach i wznoszeniu fundamentów, grono przyjaciół z parafii św. Józefa wraz z ks. proboszczem Janem Albertem z Arnhem w Holandii oraz wielu bezimiennych ludzi z Dąbrowy Tarnowskiej i okolic, którzy przez siedem lat swoją pracą, ofiarą i modlitwą wspierali budowę powstającej instytucji. Budowę Hospicjum, która trwała blisko 7 lat, rozpoczęto w 1991 roku. Pomimo szeregu ogromnych trudności oraz ciągłego braku środków (Hospicjum powstawało wyłącznie z ofiar wiernych), prace budowlane zakończono pod koniec 1998 roku.

Doniosłym wydarzeniem w tym okresie było wmurowanie kamienia węgielnego poświęconego przez Ojca Świętego Jana Pawła II (15 sierpnia 1990 roku w Castel Gandolfo), w dniu 27 czerwca 1993 roku, w czasie Jubileuszu 6oo-lecia parafii i $300-l e c i a$ nadania praw miejskich Dąbrowie Tarnowskiej, z udziałem Nuncjusza Apostolskiego ks. abpa Józefa Kowalczyka, ks. bpa ordynariusza Józefa Życińskiego oraz ks. bpa polowego WP Leszka Głodzia.

Projektu nie udało się zrealizować według pierwotnych zamierzeń (miał powstać obiekt na planie czworoboku, na około sto sześćdziesiąt miejsc). Z braku funduszy ograniczono się do wybudowania jednego budynku mieszczącego siedemnaście łóżek dla chorych Hospicjum i trzydzieści trzy miejsca dla przewlekle chorych pensjonariuszy Domu Pomocy. Przed ukończeniem prac budynek został przekazany Caritas Diecezji Tarnowskiej.

Poświęcenia kaplicy dokonał ks. bp ordynariusz Wiktor Skworc 29 sierpnia 1998 roku przy współudziale fundatorów, licznych kapłanów, przedstawicieli władz i rzeszy wiernych.

Dnia 28 grudnia 1998 roku dyrektor Caritas Diecezji Tarnowskiej, ks. Antoni Mikrut, wydanymi aktami erekcyjnymi powołał do istnienia Hospicjum Św. Brata 
Alberta, którego celem jest sprawowanie opieki medycznej, psychologicznej, duchowej, religijnej i społecznej nad osobami chorymi głównie na chorobę nowotworową, w jej zaawansowanej, końcowej fazie oraz Dom Pomocy Społecznej Św. Brata Alberta, którego zadaniem jest świadczenie usług opiekuńczych wobec osób starszych, przewlekle chorych, niepełnosprawnych.

Funkcję dyrektora placówek Caritas otrzymała od ks. bpa Ordynariusza Pani Urszula Mróz, nominację na kapelana Hospicjum i DPS otrzymał ks. prałat Józef Poremba.

\section{Istota opieki hospicyjnej}

Istota opieki hospicyjnej ma swoje źródło w ewangelicznej przypowieści o miłosiernym Samarytaninie (Łk 10, 30-35). Przypowieść ta pokazuje nam wyraźnie, jaki powinien być nasz stosunek do cierpiącego człowieka. Nie wolno nam go mijać, przechodzić obojętnie obok. Być dobrym hospicjantem, to być prawdziwym Samarytaninem - to zatrzymać się przy cierpieniu drugiego człowieka, jakiekolwiek ono by nie było. Nie chodzi tu bynajmniej o zatrzymanie z ciekawości, ale o gotowość pomocy. Trzeba wewnętrznej dyspozycji serca, aby zobaczyć chorego i wzruszyć się. Nie można jednak na tym poprzestać. Wzruszenie i współczucie, muszą przerodzić się w działanie. Cierpiącemu człowiekowi trzeba pomóc i to pomóc skutecznie, dlatego jeżeli jest taka konieczność, trzeba nawet dopłacić. Bardzo istotne jest również, aby umieć zaangażować innych do pomocy, bo jedna osoba może nie dać rady.

Istota opieki hospicyjnej czerpie również wiele z postawy Maryi stojącej pod krzyżem swojego Syna. Jej postawa, pozornie bierna, obrazuje najdoskonalej to, co wyraża głębia słowa „towarzyszenie”. Maryja mężnie „stała”, oddając siebie i przyjmując do swego serca ogrom cierpienia Jezusa. Bezradność wobec tego, co się działo, nie stała się dla niej tragedią. Ona rozumiała, że tak trzeba ponieważ taka jest cena zbawienia człowieka i we wszystkim zgadzała się z wolą Boga.

Podobnie i ludzie hospicjum starają się trwać przy umierającym człowieku, nie odchodząc od niego, nie uciekając się do niepotrzebnego już w tym momencie działania czy zbędnej krzątaniny, które często wypływają z poczucia własnej niemożności i lęku przed trudem towarzyszenia.

Oni chcą trwać, ofiarując ciepło swoich rąk, bezinteresowną miłość i „pozwolenie" na odejście, bo rozumieją, że życie człowieka wraz ze śmiercią nie kończy się, lecz jedynie zmienia, a hospicjum nie jest „umieralnią”, lecz gościnnym miejscem przechodzenia w inny wymiar życia człowieka. 


\section{Zasady opieki hospicyjnej}

Działający dziś tak prężnie w całym świecie ruch hospicyjny odsłania problem śmierci człowieka i pomaga godnie przeżywać ostatni etap ludzkiego życia.

Czyni to poprzez łagodzenie cierpienia, które przecież nie jest wartością samą w sobie, używając wszelkich możliwych środków medycznych i farmaceutycznych oraz towarzyszenie umierającemu człowiekowi aż do chwili odejścia z tego świata.

Aby czynić to możliwie najlepiej, opieka hospicyjna opiera się na podstawowych zasadach:

1. Ukierunkowanie na leczenie objawów (ból, wymioty, duszność, depresja, odwodnienie, zaparcia itp.). Chodzi o to, aby zminimalizować je do granic możliwości w sposób, który pozwala zachować przytomność i świadome przeżywanie ostatniego okresu życia.

2. Traktowanie pacjenta jako osoby, a nie jednostki chorobowej, co łączy się nierozerwalnie $\mathrm{z}$ :

- zapewnieniem warunków socjalno-bytowych godnych człowieka oraz możliwością współudziału chorego w leczeniu, poprzez decydowanie o kształcie i zakresie opieki;

- zachowaniem prawa do własnych poglądów i ochrony własnej tożsamości;

- zachowaniem prawa do życia (opieka hospicyjna alternatywą dla eutanazji);

- zachowaniem prawa do śmierci (chodzi o możliwość zrezygnowania z leków lub bezcelowych zabiegów diagnostycznych czy interwencyjnych, których działanie jedynie przedłuża bolesny proces umierania np. reanimacja).

3. Objęcie opieką również najbliższej rodziny chorego tak podczas trwania choroby, jak i w okresie żałoby po jego odejściu (chodzi o umiejętność wysłuchania, wyjaśnienia, towarzyszenie, fachową serdeczną rozmowę);

4. Włączaniu w opiekę nad chorym jego rodziny, nie tylko dlatego, że opieka ta jest jej obowiązkiem moralnym. Pomoże im to, a zwłaszcza dzieciom, oswoić się z rzeczywistością umierania. Umieranie jest bowiem naturalną i nieodzowną częścią życia każdego człowieka;

5. Opiekę nad chorym sprawuje zespół ludzi wzajemnie się wspierających i uzupełniających, w skład którego wchodzą: lekarze, pielęgniarki, kapłan, psycholog, rehabilitant, pracownik socjalny i wolontariusz niemedyczny.

6. Opieka jest towarzyszeniem, a więc jest opieką ciągłą, sprawowaną niezależnie od tego czy pacjent przebywa w domu, w szpitalu czy hospicjum stacjonarnym (dotyczy Hospicjum Domowego). 
Wymienione zasady mają na celu przede wszystkim ograniczyć do minimum tzw. „ból totalny”, którego doświadcza w szczególny sposób człowiek chory na nowotwór.

Ból ten, zwany inaczej „wszechogarniającym”, zwraca uwagę nie tylko na cierpienie fizyczne. $\mathrm{W}$ równej mierze akcentuje cierpienie $\mathrm{w}$ wymiarze emocjonalnym, społecznym i duchowym.

Musimy mieć świadomość niezmiernie trudnej sytuacji osób chorych i ich najbliższego otoczenia i musimy poszukiwać różnych sposobów zaradzania ich potrzebom. „Pomóż mi”, „Wysłuchaj mnie”, „Zostań ze mną” - główne życzenia osób chorych nieuleczalnie sformułowane przez Cicely Saunders, mające źródło w ogromnym poczuciu samotności, nieuśmierzonym bólu i wrażeniu utraty godności ludzkiej. Wychodzenie im naprzeciw to zadanie ludzi hospicjum.

\section{Informacja o placówkach}

\section{Hospicjum Św. Brata Alberta w Dąbrowie Tarnowskiej}

\section{Zakres działalności:}

Holistyczna opieka medyczna nad osobami chorymi będącymi w końcowej fazie, niepoddającej się leczeniu przyczynowemu choroby, głównie choroby nowotworowej.

Udzielana pomoc skupia się przede wszystkim na:

- leczeniu objawów choroby (ból, duszność, wymioty itd.),

- pielęgnacji,

- pomocy psychologicznej i duszpasterskiej,

- rehabilitacji,

- pomocy w zakresie spraw socjalnych,

- towarzyszeniu i trwaniu do końca przy chorym w trudnej chwili odchodzenia do wieczności,

- wspieraniu rodzin w przeżywaniu czasu choroby i śmierci swoich najbliższych, a także w trudnych chwilach żałoby (organizowane „Spotkania Rodzin Osieroconych").

Dla pacjenta pobyt w Hospicjum jest nieodpłatny.

13 lat działalności Hospicjum to:

- 17 lóżek całodobowej opieki stacjonarnej; 
- 25 zatrudnionych wykwalifikowanych pracowników: lekarze, pielęgniarki, rehabilitant, pracownik socjalny, psycholog, kapelan, pokojowe, prac. administracji oraz prac. gospodarczy;

- 1998 objętych opieką chorych;

- 343200 wykonanych iniekcji;

- 41600 podłączonych kroplówek;

- 85800 opatrzonych ran;

- 5940 założonych wenflonów i wkłuć centralnych;

- 13200 porad psychologa;

- 112 Spotkań Rodzin Osieroconych;

- 245 wieczornic, akademii, spektakli, spotkań;

- 920 Studentów PWSZ Wydział Pielęgniarski odbyło praktyki zawodowe;

- $\mathbf{1 3 0}$ wolontariuszy zaangażowanych w opiekę nad chorymi;

- 8 Festynów Charytatywnych dla Hospicjum.

\section{Dom Pomocy Społecznej Św. Brata Alberta w Dąbrowie Tarnowskiej}

\section{Zakres działalności:}

Zapewnienie przewlekle chorym osobom (mieszkańcom Domu), całodobowej opieki kompleksowej oraz zaspokojenie ich niezbędnych potrzeb bytowych, zdrowotnych, religijnych i społecznych poprzez:

- dobre warunki mieszkalne (pokoje 1 i 2-u osobowe wyposażone w meble, sprzęt oraz pościel);

- całodobową opiekę pielęgniarską;

- usprawnianie ruchowe pod opieką rehabilitanta, przy pomocy sprzętu rehabilitacyjnego oraz fizjoterapii;

- różnorodne formy zajęć terapeutycznych w świetlicy terapii zajęciowej;

- ułatwienie dostępu do kultury, oświaty i rekreacji, (organizacja wycieczek, wieczornic, akademii, koncertów itp., dostęp do prasy oraz książek);

- zapewnienie opieki duszpasterskiej: codzienna msza święta w kaplicy Domu z możliwością wysłuchania w pokojach (wyposażenie w radiowęzeł), organizacja różnych nabożeństw, możliwość rozmowy z kapłanem, zapewnienie warunków godnego umierania, a w razie śmierci organizacja pogrzebu.

\section{3 lat działalności Domu Pomocy Społecznej to:}

- 33 łóżka całodobowej opieki stacjonarnej; 
- 34 zatrudnionych wykwalifikowanych Pracowników: pielęgniarki, rehabilitant, pracownik socjalny, psycholog, kapelan, opiekunki, pokojowe, kierowca, pracownicy administracji oraz pracownicy gospodarczy;

- 111 osób objętych opieką przewlekle somatycznie chorych;

- 72200 wykonanych iniekcji;

- 23800 opatrzonych ran;

- 1200 porad psychologa;

- 11150 wizyt Lekarza POZ;

- 39200 zabiegów rehabilitacji i fizjoterapii;

- 240 wieczornic, akademii, spektakli, spotkań;

- 20 młodocianych pracowników zdobyło zawód Kucharz Małej Gastronomii;

- 118 studentów i słuchaczy odbyło praktyki z zakresu pracy socjalnej oraz opiekuna osoby niepełnosprawnej;

- $\mathbf{1 2 0}$ wolontariuszy pomagało w opiece nad pensjonariuszami.

\section{Ważniejsze wydarzenia}

1 kwietnia 1999 roku. Rozpoczęcie działalności, przyjęcie pierwszych podopiecznych do Placówek.

Maj 1999 roku. Pierwsze Spotkanie Rodzin Osieroconych. Spotkania modlitewno-wspierające dla rodzin zmarłych pacjentów. (Od 2004 roku wprowadzono stały termin spotkań w każdą pierwszą sobotę miesiąca o godzinie 10:00). Do tej pory łącznie w spotkaniach wzięło udział kilkanaście tysięcy osób osieroconych. Część z nich przyjeżdża systematycznie od kilku lat. Każdego roku na spotkanie w pierwszą sobotę miesiąca listopada są zapraszane rodziny wszystkich, którzy odeszli do wieczności w Hospicjum i w Domu Pomocy w mijającym roku.

16 czerwca 1999 roku. Wspólny udział podopiecznych i pracowników w uroczystościach papieskich w Starym Sączu (VI pielgrzymka Ojca Świętego Jana Pawła II do Ojczyzny, kanonizacja bł. Kingi).

Styczeń 2000 roku. I Spotkanie Opłatkowe Pracowników z udziałem dyrekcji Caritas Diecezji Tarnowskiej, władz samorządowych miasta i powiatu oraz przedstawicieli innych instytucji współpracujących i wspomagających naszą działalność. Spotkania kontynuowane są nadal w formie kolacji wigilijnej w każdą wigilię Bożego Narodzenia.

11 lutego 2000 roku. Pierwsza uroczystość z okazji Światowego Dnia Chorego z udziałem ks. bpa ordynariusza Wiktora Skworca (msza święta, udzielanie sakramentu chorych, agapa). 
Maj 2000 roku. Pierwsze spotkanie pracowników i podopiecznych z diakonami WSD w Tarnowie poprzedzone prelekcją o idei i zasadach opieki hospicyjnej. Spotkania są kontynuowane nieprzerwanie do tej pory. Diakoni, już jako neoprezbiterzy przyjeżdżają ponownie, aby odprawić mszę świętą w hospicyjnej kaplicy i udzielić naszej wspólnocie prymicyjnego błogosławieństwa.

Listopad 2000 roku. Rok Jubileuszowy przebiegający pod hasłem: „Z Maryją wielbimy Boga w Trójcy Świętej". Wyjątkowe Spotkanie Rodzin Osieroconych (rodziny osób zmarłych w Hospicjum w całym 2000 roku) w kościele parafialnym w Dąbrowie Tarnowskiej. Kościół pw. Najświętszej Marii Panny Szkaplerznej był jednym z 18 kościołów diecezji, do których przywiązany był specjalny odpust jubileuszowy.

Luty 2001 roku. Początki posługiwania wolontariuszy. W okresie 14-letniej działalności posługę wolontariusza Hospicjum i DPS Św. Brata Alberta pełniło kilkaset osób - głównie uczniów z miejscowych i okolicznych szkół. Najbardziej zaangażowani to uczniowie Zespołu Szkół Ponadgimnazjalnych nr 1 w Dąbrowie Tarnowskiej z opiekunami - panią Barbarą Irla, panią Małgorzatą Ziobro oraz ks. Henrykiem Kołodziejem, Zespołu Szkół Ponadgimnazjalnych nr 2 w Dąbrowie Tarnowskiej z opiekunem panią Zofią Rzepecką, Gimnazjum w Lisiej Górze z opiekunami: panią Bernadetą Kolasa oraz panią Elżbietą Huczek. Szkolne Koło PCK przy Gimnazjum nr 1 w Dąbrowie Tarnowskiej z opiekunami: panią Haliną Barabasz i panią Katarzyną Wójcik. Pracę wolontariuszy zawsze poprzedza kilka spotkań wprowadzających oraz uroczyste przyrzeczenie w kaplicy podczas Eucharystii złożone w obecności księdza kapelana.

\section{Z karty etycznej wolontariusza}

„Będę sumiennie spełniać wszystkie zadania związane z przyjętą rolą.

Nie będę składać obietnic, których nie jestem $w$ stanie spełnić.

Zachowam dyskrecję, będę unikać zachowań, które mogą być źle zrozumiane. Wykorzystam szansę poznania i nauczenia się nowych rzeczy od innych osób. Nie będę krytykować rzeczy i spraw, których nie rozumiem.

Będę osobą, na której można polegać.

Będę się chętnie uczyć, ponieważ nauka jest nieodłączną częścią każdej pracy. Zrobię wszystko, aby być jak najlepszym wolontariuszem.

Oby Bóg mógł posłużyć się moimi wysiłkami dla swojego dzieła. Nie ja, lecz Bóg we mnie" (Dag Hammarskjöld)

\section{Pomimo wszystko}

Człowiek jest nierozumny i egocentryczny nieważne: i tak go kochaj! 
Chciałbyś zrobić coś wspaniałego, ale inni źle oceniają twoje intencje nieważne: i tak zrób to!

Wypełniając swe obowiązki

znajdziesz fałszywych przyjaciół i prawdziwych nieprzyjaciół nieważne: wypełniaj je i tak!

Dobro, które czynisz, jutro jest zapomniane nieważne: czyń tak dalej!

Uczciwość, szczerość, przejrzystość, czynią cię słabym i bezbronnym nieważne: nadal bądź uczciwy i szczery!

To, co budujesz od lat, może być zniszczone w jednym momencie nieważne: i tak buduj dalej!

Pomagasz ludziom, a oni tego nie zauważają nieważne: pomagaj im nadal!

Pragniesz oddać to, co w tobie najlepsze, a inni zniewalają cię i odrzucają nieważne: nieustannie dawaj to co $\mathrm{w}$ tobie najcenniejsze!

Matka Teresa z Kalkuty

26 maja 2001 roku. Peregrynacja Obrazu Matki Bożej Jasnogórskiej w parafiach diecezji tarnowskiej, godzinny „postój” Cudownego Obrazu w samochodzie, na pochylni budynku. Zawierzenie Hospicjum Matce Bożej Jasnogórskiej przez dyrektora placówek.

„Maryjo-Matko Boga i Matko każdego z nas. Stajemy przed Twoim obliczem a Ty pełna dobroci, miłości i miłosierdzia patrzysz w nasze serca. Tyle w nich trosk, smutku, naszej ludzkiej bylejakości. Nasza miłość do Boga i do człowieka taka marna.... Maryjo przez Twoją dobroć i miłość proszę - ratuj nas od egoizmu, od poddawania się rozpaczy, od buntu przeciwko woli Boga. Pomóż abyśmy zawsze byli Twoimi dziećmi.

Tobie Maryjo zawierzam nas wszystkich. Tych, których spodobało się Panu doświadczyć cierpieniem oraz tych, których porwała Miłosierna Miłość i chcą im służyć na miarę własnych sił.

Maryjo proszę, otaczaj nas nieustannie Twoją opieką. Obdarz nas Twoja dobrocią, abyśmy poprzez dobroć naszych serc zasłużyli na Niebo. Proszę - przez Twoją pokorę i bezgraniczną ufność - naucz nas zawsze wypowiadać Bogu fiat niech się stanie - niech się stanie Twoja wola Boże w moim życiu, moim cierpieniu, w moim niepowodzeniu. Przez Twoją bezgraniczną Miłość, pomóż nam kochać każdego człowieka tak jak Ty kochałaś Jezusa Chrystusa, tak jak Ty nas kochasz bezwarunkowo i wiernie. Maryjo zawsze wierna, wybłagaj nam łaskę, abyśmy byli zawsze wierni Bogu w Trójcy Świętej Jedynemu, abyśmy zawsze byli wierni Tobie. 
Maryjo pełna łaski - bądź przy nas w każdej życia chwili i ubogacaj nas abyśmy podołali w naszym powołaniu, w naszej służbie człowiekowi, abyśmy umieli łączyć nasze cierpienia, samotność czy ból, z krzyżem Twojego Syna. Abyśmy umieli ofiarować je dla zbawienia wszystkich ludzi na całym świecie.

Spraw niech zawsze w naszych sercach brzmią Twoje słowa: «Uczyńcie, co wam mówi Syn» i wspomagaj, aby nasza wiara i miłość nigdy nie kończyła się na słowach, ale okazywała się w czynach miłosierdzia wobec drugiego człowieka.

Matko Miłosierdzia w tym szczególnym miejscu zawierzamy Tobie dusze wszystkich zmarłych w Hospicjum. Niech ogrom ich cierpienia będzie dla nich bramą do wiecznej radości z Tobą. Wszystkich osieroconych: rodziców, dzieci, małżonków, uchroń przed rozpaczą, ukazuj im Zmartwychwstałego Syna i pomóż zrozumieć, że śmierć jest jedynie przejściem do prawdziwego życia - życia w Bogu.

Maryjo w ciszy naszych serc jeszcze raz zawierzamy się Tobie. Nasze ciała i dusze Nasze serca i wszystko to, co w nich najdroższe.... Spraw abyśmy byli godnym narzędziem Twojego Syna i Twoim w zbawianiu świata i ukazywaniu mu Chrystusowej Miłości".

9-10 sierpnia 2002 roku. Ogólnopolskie Spotkanie Forum Ruchu Hospicyjnego z udziałem przedstawicieli 39 hospicjów z całej Polski. Spotkanie szczególne - Polski Ruch Hospicyjny zgromadził się u stóp Miłosiernego Chrystusa w Hospicyjnej kaplicy, aby właśnie tu rozważać trudne problemy, podejmować decyzje i powierzać Jego Miłosierdziu wszystkie polskie hospicja, w przeddzień pielgrzymki Jana Pawła II do Łagiewnik i zawierzenia całego świata Bożemu Miłosierdziu.

17 grudnia 2002 roku. Koncert dobroczynny: „Gwiazdy dla Hospicjum Św. Brata Alberta w Dąbrowie Tarnowskiej” na deskach Teatru im. Ludwika Solskiego w Tarnowie. Prowadzenie: Michał Juszczakiewicz. Wystąpili: Justyna Steczkowska, Agnieszka Chrzanowska, Michał Zabłoci. Całkowity dochód z koncertu został przeznaczony na rzecz Hospicjum Św. Brata Alberta w Dąbrowie Tarnowskiej. Koncert odbył się dzięki staraniom pana Marcina Mikosa oraz dzięki życzliwości dyrekcji tarnowskiego teatru.

Październik 2003 roku. Rok Różańca - peregrynacja różańca w dąbrowskiej parafii oraz wśród podopiecznych DPS. Różaniec pozostał w naszej kaplicy jako pamiątka. Codziennie na tym różańcu jest odmawiana Koronka do Bożego Miłosierdzia, a także różaniec za zmarłych podczas Spotkań Rodzin Osieroconych.

15 sierpnia 2004 roku. Pierwszy Wielki Festyn Charytatywny dla Hospicjum organizowany przez pracowników Hospicjum i DPS z pomocą wolontariuszy, członków Stowarzyszenia Św. Brata Alberta i wielu ludzi dobrej woli. Festyny stały się tradycją. Pozwalają na zdobycie dodatkowych środków finansowych na zakup specjalistycznego sprzętu medycznego oraz bieżącą działalność. Organizatorzy każdego roku zwracają się do ludzi dobrej woli z prośbą o sfinansowanie 
głównej nagrody w loterii lub przekazanie różnych gadżetów, zabawek, książek, przedmiotów itp., które zostają wykorzystane jako fanty. Festyny odbywają się na terenie Parafialnego Ośrodka Sportu i Rekreacji obok Hospicjum. Zapewniają wiele atrakcji dla dzieci, młodzieży i dorosłych. Mają miejsce między innymi: zawody sportowe, konkursy, zabawy, turniej piłki plażowej o Przechodni Puchar Hospicjum, loteria fantowa (każdy los bierze dwukrotnie udział w losowaniu!), a także parada motocyklistów, pokaz sprzętu strażackiego oraz zabawa taneczna. Ogromnym powodzeniem cieszy się "najlepszy w Europie” bigos, lody, domowe ciasto oraz grilowe przysmaki. To wszystko, „doprawione” miłosierną Miłością darczyńców, stwarza niepowtarzalną atmosferę.

Do tej pory ze środków uzyskanych podczas festynów udało się zakupić m.in.: wózek do przewożenia chorych leżących, pompę infuzyjną, kilkanaście zmiennociśnieniowych materacy, trzy łóżka hydrauliczne, dwa ssaki medyczne dwustanowiskowe, pulsoksymetr, podnośnik elektryczny oraz aparat do EKG.

Październik 2004 roku. Udział Hospicjum Św. Brata Alberta w Ogólnopolskiej Kampanii Hospicyjnej: „Zdążyć z prawdą - Hospicjum to też Życie”. Celem kampanii jest propagowanie idei hospicyjnych oraz uwrażliwienie społeczeństwa na uczucia, potrzeby i problemy ludzi chorych na choroby nowotworowe.

W ramach Kampanii, w zabytkowym kościele pw. Wszystkich Świętych w Dąbrowie Tarnowskiej odbył się koncert Kleryckiego Zespołu Genezaret z Wyższego Seminarium Duchownego w Tarnowie, dostarczając wiele duchowych przeżyć i wzruszeń. Koncert zgromadził liczne grono młodzieży, wolontariuszy, pracowników i przyjaciół Hospicjum. W ramach Kampanii Ludzie Hospicjum zorganizowali również debatę na temat: „Nieuleczalna choroba - jak o tym mówić”. Debata była kierowana szczególnie do osób zainteresowanych problemami ludzi chorych $\mathrm{z}$ racji wykonywanego zawodu czy też charytatywnej działalności w różnych stowarzyszeniach.

Luty 2005 roku. Kanoniczna wizytacja w dąbrowskiej parafii. Spotkanie ks. bpa ordynariusza Wiktora Skworca z chorymi i pracownikami Hospicjum i DPS $\mathrm{w}$ ramach tejże wizytacji.

11 lutego 2009 roku. Diecezjalne obchody XVII Światowego Dnia Chorego pod hasłem: „Otoczmy troską chorych”. Uroczystej mszy świętej odprawionej w kaplicy Hospicjum, transmitowanej przez diecezjalne Radio RDN - Małopolska, przewodniczył J. E. ks. bp Wiktor Skworc - ordynariusz tarnowski. Wcześniej ks. Biskup spotkał się z pensjonariuszami Domu Pomocy Społecznej i chorymi Hospicjum. W uroczystości wzięli udział przedstawiciele wszystkich placówek Caritas z terenu diecezji, kapłani okolicznych parafii, władze miasta i powiatu oraz przedstawiciele wszystkich placówek służby zdrowia z Dąbrowy Tarnowskiej. 
20 maja 2009 roku. Sympozjum naukowe organizowane przez Hospicjum Św. Brata Alberta w Dąbrowie Tarnowskiej pt. „Otoczmy troską chorych terminalnie”, pod patronatem J. E. ks. bpa Wiktora Skworca oraz burmistrza miasta Dąbrowa Tarnowska pana Stanisława Początka, z okazji 10-lecia działalności placówki. Sympozjum miało miejsce w siedzibie DDK.

\section{Tematy wykładów naukowych Sympozjum:}

Opieka paliatywna - podstawowe zasady i aktualne problemy

Wykładowca: dr med. Tomasz Grądalski - Hospicjum im. Św. Łazarza w Krakowie

Małopolski Konsultant Wojewódzki Medycyny Paliatywnej

Postępy w leczeniu onkologicznym: czy już czas na zmianę paradygmatu?

Wykładowca: dr med. Andrzej Radkowski - Zakład Radioterapii

z Oddz. Radioterapii Szpitala Woj. im. Św. Łukasza w Tarnowie

Rozpoznawanie i leczenie ostrej zatorowości płucnej

Wykładowca: dr n. med. Bożena Ziółkowska-Graca - II Katedra Chorób Wewnętrznych CMUJ Kraków

Dylematy etyczne w opiece paliatywnej

Wykładowca: ks. dr Antoni Bartoszek - adiunkt w Zakładzie Teologii Moralnej i Duchowości Wydziału Teologicznego Uniwersytetu Śląskiego w Katowicach, kapelan Ośrodka dla Niepełnosprawnych w Rudzie Śląskiej

Specjalistyczne opatrunki - profilaktyka i leczenie ran trudnogojących

Wykładowca: mgr Jakub Bielski - przedstawiciel „Hartman Polska” z Pabianic

17 czerwca 2009 roku. Główne uroczystości 10-lecia działalności Hospicjum i DPS. Jubileuszowy odpust ku czci św. Brata Alberta - patrona placówek z udziałem dyrekcji Caritas diecezji tarnowskiej oraz byłych księży dyrektorów CDT: ks. Antoniego Mikruta, ks. Zbigniewa Pietruszki, ks. Leszka Rojowskiego. Byli księża dyrektorzy, ks. kapelan Józef Poremba oraz Stowarzyszenie Pomocy Św. Brata Alberta w Dąbrowie Tarnowskiej otrzymali z rąk ks. dyrektora Ryszarda Podstołowicza statuetki „MISERICORS” za zaangażowanie na rzecz Hospicjum oraz w działalność charytatywną Caritas.

28 czerwca 2011roku. Jubileusz 50-lecia święceń kapłańskich ks. prałata Józefa Poremby kapelana placówek. Uroczysta msza święta z udziałem dyrekcji CDT, pracowników oraz podopiecznych. Okolicznościowa agapa. 


\section{Wyróżnienia}

Dyplom - wyróżnienie ks. bpa Ordynariusza za działalność charytatywną podczas święta Caritas przed Niedzielą Miłosierdzia Bożego w 2001 roku.

Wyróżnienie i nagroda pieniężna Polcul Fundation za działalność hospicyjną. Fundacja polsko-australijska popierania niezależnej kultury polskiej w Sydney, z siedzibą w Warszawie (2002 rok).

Statuetka „Dobry dla innych” przyznawana przez kapitułę Center Med w Tarnowie (2005 rok).

Wyróżnienie - „Kryształy Soli 2010” - nagroda marszałka województwa małopolskiego w kategorii zdrowie dla najlepszych małopolskich organizacji prowadzących działalność PP.

Wyróżnienie - „Miłosierny Samarytanin 2010” w kategorii służba zdrowia (siódma edycja ogólnopolskiego plebiscytu organizowanego przez Wolontariat św. Eliasza w Krakowie).

\section{Media o nas}

\section{Urszula Skórka, Hospicjum - tu tė̇ życie}

Ulica św. Brata Alberta Chmielowskiego jest usytuowana z dala od zgiełku miasta. Wszechobecna zieleń, oddalenie od centrum i cisza stwarzają wrażenie jakby w tym miejscu czas się zatrzymał lub przynajmniej płynął znacznie wolniej.

Po jednej stronie ukryty w gąszczu zieleni stary cmentarz wojenny, po przeciwnej duży, trzykondygnacyjny budynek z wielkim białym krzyżem. Przed budynkiem, wśród kwiatów i krzewów figura św. Brata Alberta. Nad wejściem widnieje tablica ze znakiem „Caritas” i wyraźnym napisem: Hospicjum i Dom Pomocy Społecznej im. św. Brata Alberta w Dąbrowie Tarnowskiej. Poniżej wmurowano kamień węgielny poświęcony przez Jana Pawła II i medalion z brązu z wizerunkiem św. Brata Alberta. Wewnątrz świeża zieleń ścian zestawiona $\mathrm{z}$ soczystym drewnem okiennych futryn i framug drzwi. Obszerny korytarz oświetlony dzięki dużym oknom i przeszklonym drzwiom prowadzi do kaplicy. Na ścianach obrazy i kwiaty. Gdzie ta „umieralnia” utrwalona w przeświadczeniach społecznych? Gdzie przykry zapach lizolu i szpitalna krzątanina? Gdzie samotność i obojętność przytułku? Rzeczywistość całkowicie odbiega od powszechnych wyobrażeń. Nie mieści się w wąskich ramach społecznych przesądów. 


\section{Moje miejsce na ziemi}

Dyrektor hospicjum Urszula Mróz z życzliwym uśmiechem zaprasza do swojego gabinetu. $\mathrm{Z}$ zawodu i powołania jest pielęgniarką. Ciąży na niej odpowiedzialność zarządzania tą placówką. Pacjentom tak poważnie chorym i umierającym nie może niczego zabraknąć. Wszystko musi być „zapięte na ostatni guzik”. Wciąż dzwonią telefony.

- Czy nie miała Pani kiedyś tego wszystkiego dość?

- Nie, mimo że nieraz bywało bardzo trudno. Postrzegam moją pracę jako powołanie. To była moja świadoma decyzja - mówi z przekonaniem. - Coś wybrałam i chcę pozostać wierna temu wyborowi. Jestem przekonana, że praca whospicjum to moje miejsce na ziemi.

Pytam o pacjentów, którzy zapadli Pani Dyrektor w pamięć. Wyjątkowo ciężkie przypadki, przytłaczające tragedie, odwaga i walka aż do końca...

- Było ich tak wielu, a w dodatku nie sposób w kilku słowach opowiedzieć czyjąś śmierć, tragedię czy trudną sytuację... Podczas blisko dziewięcioletniej działalności objęliśmy opieką 1070 osób. Najmłodszy pacjent miał zaledwie 11 lat, a $140 \mathrm{~kg}$ wagi czyniło go prawie dorosłym. Towarzyszyliśmy do końca osobom na progu życia, w sile wieku, a także staruszkom.

Nie łatwo patrzyć codziennie na ból i śmierć pacjentów. Jeszcze trudniej towarzyszyć im aż do końca.

- Odchodzili u nas kapłani, ojcowie rodzin, matki mające jeszcze małe dzieci, i dzieci wprawdzie dorosłe, ale dla swoich rodziców zawsze odchodzące za wcześnie. Nie jeden raz zaskakiwała nas ich odwaga wobec tak trudnej sytuacji, cierpienia i śmierci.

„Spieszmy się kochać ludzi tak szybko odchodzą" chciałoby się powtórzyć słowa poety, ale trudno cokolwiek powiedzieć.

- Bywały bardzo trudne, nazwałabym to „przypadki medyczne”, gdzie opieka nad takim pacjentem wymagała samozaparcia ze strony personelu (olbrzymie rozległe rozpadające się guzy nowotworowe, które często trzeba opatrywać, aby odór gnijących ran nie był dodatkowym cierpieniem dla chorego). W hospicjum nie ma lekkich przypadków.

Rzeczywiście - spektrum chorób nowotworowych, z którymi zetknął się personel hospicjum jest rozległe. Medycyna paliatywna obejmuje najcięższe schorzenia.

W hospicjum opieką nad pacjentem zajmuje się interdyscyplinarny zespół: lekarz, pielegniarki, dietetyk, rehabilitant, fizykoterapeuta, psycholog, duchowny oraz specjalnie przygotowani, wolontariusze. Chorym, cierpiącym i umierającym nie brakuje opiekuńczych rąk, obecności drugiej osoby i życzliwego słowa. 
Personel medyczny dokłada wszelkich starań, by uśmierzyć ból i towarzyszyć pacjentom aż do końca.

Pani dyrektor mówi po chwili zastanowienia:

- To bardzo trudne być przy człowieku pozbawionym nadziei na wyzdrowienie, towarzyszyć mu w odchodzeniu, a także być $\mathrm{z}$ jego rodziną $\mathrm{w}$ najtrudniejszych momentach i wspierać, gdy świadomość utraty kogoś najbliższego często przerasta siły.

Chwila ciszy - niełatwo mówić o śmierci. Człowiek staje wtedy w obliczu nieuchronności losu i swojej bezradności.

- Na pewno nie można przewidzieć swoich reakcji na różne sytuacje, nie można mieć przygotowanej gotowej formułki, co powiedzieć. Każdy inaczej przeżywa trudne chwile. Słowa nie zawsze są konieczne. Czasem wystarczy tylko milcząca obecność, czasem tylko objęcie ramion. Ważne, aby rozumieć i dać temu wyraz. Ważne, aby naprawdę chcieć pomóc.

Urszula Mróz jest stworzona do kierowania tą placówką. Jest dyrektorką hospicjum od czasu jego powstania. Zżyła się z tym miejscem i tymi ludźmi. Nie tylko kieruje hospicjum, ale też uczestniczy w jego codziennych sprawach. Nie każdy nadaje się do pracy w takim miejscu. Nie każdy dysponuje siłą psychiczną konieczną w obliczu cierpienia i śmierci. Tu nie można być zmęczonym, nie można odmówić pomocy potrzebującym.

- Na pewno potrzebne są odpowiednie kwalifikacje, ale też wrażliwość na cierpienie, opanowanie, otwartość na drugiego człowieka i chęć niesienia pomocy. Chorzy i ich rodziny oczekują od nas nie tylko profesjonalnej pomocy w zwalczaniu dolegliwości fizycznych, ale także szacunku i godnego traktowania w sytuacji często bardzo trudnej i upokarzającej dla człowieka.

Codzienność Urszuli Mróz to niewielki gabinet na parterze, plik dokumentów na biurku, załatwianie setek spraw. Ale codzienność to także kontakt z pacjentami, msza w zaciszu kaplicy (jeżeli czas pozwoli) i satysfakcja, że praca, którą wykonuje pomaga najbardziej potrzebującym.

- Jednym z głównych naszych zadań jest zapewnienie choremu godnych warunków odchodzenia i śmierci. Chodzi o eliminacje bólu i innych przykrych objawów, serdeczną obecność i towarzyszenie do końca. Staramy się trwać, ofiarując ciepło swoich rąk, modlitwę i „pozwolenie” na odejście.

Urszula Mróz, oprócz obowiązków dyrektorki hospicjum, ma jeszcze jedną „misję" - stara się zmienić społeczne wyobrażenia dotyczące opieki hospicyjnej. $\mathrm{Na}$ niedawnym festynie charytatywnym obok zabawy znalazł się czas na wspomnienie o hospicjum i promocję książki o tej placówce. Nie łatwo zmienić społeczne wyobrażenia - dla większości ludzi hospicjum nadal jest „umieralnią”. Strach 
przed śmiercią i ucieczka od tego tematu tylko umacnia błędne przekonania. „Nie śmierci się boimy, lecz myśli o śmierci” twierdził Seneka.

- Oddanie bliskiego do hospicjum bywa dużym problemem moralnym. Hospicjum często kojarzy się mylnie z przytułkiem czy „umieralnią”. Ludziom trudno dostrzec, gdzie przebiega granica między „pozbyciem się problemu”, a koniecznością stworzenia choremu najlepszych warunków na czas cierpienia i godnej śmierci. Lęk przed tym, co ludzie powiedzą często nie pozwala podjąć słusznej decyzji i skazuje chorego na odchodzenie w ogromnym bólu, a jego bliskich na cierpienie wywołane bezradnością - mówi z naciskiem Urszula Mróz. Pani dyrektor wie, że strach zwykle mija, gdy rodziny widzą, że hospicjum oferuje choremu profesjonalna opiekę, uśmierzenie bólu, troskę i serdeczność.

Widziała już wiele - od ludzkich dramatów, po uśmiech i zgodę na to, co przynosi życie. Widziała łzy i żal, który trudno ukoić i radość z każdego następnego dnia.

- Widziała pani nadzieję na wyzdrowienie i wiarę aż do końca? - pytam. Odpowiada bez chwili wahania:

- Tak, bardzo często. Nadzieja pomaga przetrwać największe przeciwności losu. Sprawia, że chory nie załamuje się mimo złych rokowań.

O eutanazji nie chce słyszeć. Uważa rozmowę na ten temat za stratę czasu. Mimo ogromu cierpienia, z którym styka się na co dzień, jest przeciwniczką eutanazji i przytacza mocne argumenty:

- Myślę, że głównym powodem osób domagających się eutanazji jest pozbycie się „problemu” jakim jest chory. O eutanazji najczęściej mówią ludzie zdrowi. Na tysiąc pacjentów, których objęliśmy opieką w hospicjum nikt nie domagał się eutanazji.

Ma lepszą „receptę” na ludzką niedolę. I mówi to z punktu widzenia osoby, dla której cierpienie i śmierć nie jest abstrakcją, bo widzi je na co dzień.

- Dajmy ludziom cierpiącym odrobinę miłości, dobroci serca i życzliwą obecność. Dostrzeżmy w nich ludzką godność, lekami uśmierzmy ból, a zapewniam - nikt z nich nie poprosi o eutanazję.

\section{„Serce” hospicjum}

Wchodzę na pierwsze piętro, gdzie znajdują się sale chorych. Jasny, przestronny korytarz, na ścianach obrazy i kwiaty. W głębi, po prawej stronie duży balkon, który pozwala pacjentom na uczestnictwo w mszy z góry. W środku korytarza świetlica, a w niej łóżko, stolik i krzesła, dwa telewizory. Po obu stronach pokoje chorych - jedno i dwuosobowe z łazienką i balkonem. Schludne i przytulne. To tutaj, na pierwszym piętrze, bije „serce” hospicjum. 
Jak wyglądają osoby pracujące przy umierających? - zastanawiam się. Pewnie są smutne i przybite widokiem cierpienia. Pewnie rzadko się uśmiechają... Podchodzi do mnie siostra zakonna $\mathrm{z}$ dwiema młodymi pielęgniarkami. Wszystkie energiczne, uśmiechnięte, radosne. Siostra o ciepłym głosie gestem ręki zaprasza mnie do dyżurki.

- Jak się pracuje z pacjentami w obliczu śmierci? Po chwili zaczyna mówić, trochę nieśmiało, siostra Dorota. Ma cichy, ciepły i kojący głos

- Myślę, że nie jest to łatwa praca. Można powiedzieć, że dołuje. Ale musimy dać z siebie wszystko, by pacjenci nie czuli się opuszczeni.

- Robimy wszystko, by im pomóc - dodaje Agnieszka. Do rozmowy włącza się Monika.

- Pacjenci też z nami współpracują. Oczywiście ci, z którymi da się współpracować, bo nie ze wszystkimi się da. Dla innych wtenczas mamy dotyk pełen czułości i to, co najważniejsze - obecność.

Zadziwiające, ile w tych pielegniarkach zrozumienia i pokory wobec cierpienia.

Tak prosta czynność, jak zwykły dotyk w hospicjum może zdziałać cuda. Wiedzą o tym pielęgniarki, które są najbliżej pacjentów:

- Wielu chorych nie odezwie się, nie uśmiechnie, nie powie. Sam uścisk dłoni, czy pogłaskanie po twarzy to dla nich dużo. Czują, że ktoś jest przy nich obecny.

\section{Przeprowadzić bezpiecznie na ,tamtą stronę"}

W dąbrowskim hospicjum jest tylko 17 łóżek, co pozwala na lepszą opiekę. Pacjenci otrzymują fachową i troskliwą opiekę oraz wsparcie psychiczne. Rodziny mogą odwiedzać bliskich bez ograniczeń. Chory odchodzi czując, że nie jest sam.

- My zawsze trafiamy na ten moment ostatni, że jest czas na zmówienie koronki, podanie gromnicy. Nie zdarza się, że przychodzimy i stwierdzamy zgon, tak jak jest wielokrotnie w szpitalu - mówi Monika.

Dzisiejsza medycyna umie zdziałać cuda. Utrzymuje człowieka przy życiu za wszelką cenę. Chodzi o to by, wszelkimi dostępnymi środkami, oddalić moment śmierci. Bo dziś śmierć jest dla lekarza porażką zawodową. Papież Pius XII uważał, że obowiązkiem lekarza jest łagodzenie bólu, a nie podtrzymywanie życia, którego nie można już uratować.

Do hospicjum trafiają najczęściej ludzie w ostatniej fazie choroby nowotworowej. Od personelu medycznego oczekują troskliwej opieki, zniesienia bólu i obecności. Chodzi o trwanie przy chorym aż do końca i umożliwienie godnej śmierci. Oni najczęściej nie czekają już na cud.

- Na pewno trzeba zrobić wszystko, co w ludzkiej mocy, aby człowiek nie cierpiał fizycznie ani duchowo. W pewnym momencie, trzeba jednak pokornie skłonić 
głowę i pozwolić odejść - to słowa Urszuli Mróz. Tylko wieloletnie doświadczenie pracy przy ciężko chorych i pokora pozwalają powiedzieć coś takiego.

- Dla nas nie ma porażki, gdy pacjent umiera, jeśli się go da bezpiecznie przeprowadzić „na tamtą stronę”. Jesteśmy koło niego, czuje ten dotyk - mówi Monika. I niespodziewanie dodaje - Nawet pacjenci się tutaj uśmiechają!

\section{Dać siebie innym}

Między pielęgniarkami, a ich podopiecznymi wytwarza się więź. Ciepłe słowo, życzliwa obecność, drobny gest zbliżają ludzi.

- Wytwarza się taka więź rodzinna między nami, pacjentami, a rodziną. My rzadko mówimy po nazwisku chorym. Przeważnie mówimy: panie Stasiu, panie Kaziu, pani Marysiu... To zbliża jednego człowieka do drugiego - mówi siostra Dorota.

Mimo własnego cierpienia pacjenci hospicjum dostrzegają także tego drugiego, który również potrzebuje pomocy.

- Oni są tacy: każdy, gdyby tylko mógł, pomógłby temu drugiemu. Pacjenci są otwarci na innych. Można się od nich uczyć tego, by nie zapatrzyć się w siebie, ale patrzeć też na drugiego. „Musisz żyć dla innych, jeśli chcesz żyć z pożytkiem dla siebie" powiedział Seneka.

W hospicjum słowa filozofa zyskują nowy wymiar, „ożywają”.

\section{Pamięć nie umiera}

Przez blisko 9 lat działalności hospicjum trafiali tu różni pacjenci. Przychodzili i odchodzili. Ale każdy pozostawił tutaj cząstkę siebie. Siostra Dorota, Monika i Agnieszka pamiętają swoich pacjentów, którzy już odeszli. Często ich wspominają. Tym razem i ja mogę uczestniczyć w tej sentymentalnej podróży do przeszłości.

Siostra Dorota przypomniała sobie Mateusza:

- Pamiętacie Mateusza (tego 2o-latka)? Taki młody, a miał cały czas na paluszku różaniec. I tak spokojniutko, cichutko sobie go odmawiał. Bez żadnej skargi. Żeby on kiedyś narzekał, a buzie miał taką! (Siostra, ze współczuciem, próbuje zobrazować twarz chłopca zdeformowaną od nowotworu). Monika i Agnieszka dobrze pamiętają Mateusza.

Przez chwilę dyżurka pielęgniarek zamienia się w krainę wspomnień. Co chwila „ożywają” tu postaci dawnych pacjentów, gesty, słowa i uśmiechy. Uśmiechają się również pielęgniarki. Siostra Dorota przypomina sobie zabawną sytuację sprzed lat: 
— Takie coś śmiesznego kiedyś było. Taki „profesor” był, pamiętacie? — zwraca się do koleżanek. - Traktował wszystkich jak w szkole. Zawsze wysyłał nas po coś mówiąc: „proszę przynieść...!” I ja go kiedyś karmię, a on mi tak [mówi]: „Piwo proszę!” A ja mu mówię: „Bardzo Pana przepraszam, ale tu jest «lokal» bezalkoholowy. Czy może być kompot?” - „Może być”.

W dyżurce rozbrzmiewa radosny śmiech.

Ale nie zawsze było wesoło. Wręcz przeciwnie - częściej płynęły łzy. Do hospicjum trafiali również bardzo młodzi ludzie. Siostra Dorota wspomina Tomka (21 lat). Wszystkie dobrze pamiętają tego chłopca.

- Tomek sam przygotowywał rodziców do własnego odejścia. On był bardzo mądry i naprawdę bardzo pięknie przygotowywał rodziców do swojego odejścia. I dużo z nimi na ten temat rozmawiał. To dla nas było szokiem - opowiada Monika. Patrzę na moje rozmówczynie, mają łzy w oczach.

Chrześcijański myśliciel Landsberg napisał: „Wszelka walka ze śmiercią jest daremna i z góry przegrana. Piękno jej nie polega na wyniku, lecz na pełnym godności wyjściu naprzeciw śmierci”. Śmierć Tomka była piękna. I przedwczesna.

— Tomek mówił rodzicom, że on pójdzie wcześniej, żeby im tam przygotować miejsce - słyszę cichy głos siostry.

Po chwili milczenia ciszę przerywa Monika:

- Tomek powiedział rodzicom, że nie zdążą. Na ostatni moment nie zdążą. I nie zdążyli. Faktycznie nie zdążyli... - milknie, by po chwili dodać: - Taki był życiowo mądry.

Co by w tej sytuacji powiedział Seneka? „Przez całe życie trzeba się uczyć umierać".

Wychodzę z hospicjum. Jeszcze tylko ostatnie spojrzenie i kilka zdjęć. Ksiądz-poeta Jan Twardowski pytał: „Mój Boże, jak pojąć serce śmierci?”. Nie wiem... Ale jedno wiem - mimo, że tutaj, w Hospicjum, ludzie odchodzą, to nie jest „umieralnia”. Tutaj też jest życie. Do samego końca. („Temi” 2007). 